\title{
Peertechz
}

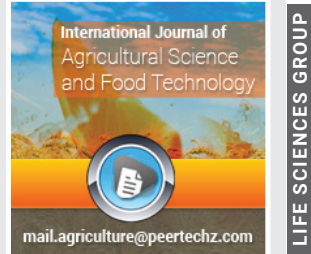

\section{Assessment of the extent} implementing the Good Manufacturing Practices (GMPs) and Hazard Analysis Critical Control Point System (HACCP) in Sudan sugar industry factories

\section{AM Babeker', Al Ahmed', AR Ahmed ${ }^{2}$ and Mohammed} Alhadi Ebrahiem ${ }^{3 *}$

'Department of Food Science and Technology, Faculty of Natural Resources and Environmental Studies, University of Kordofan, Elobeid, Sudan

${ }^{2}$ Ahfad University for Women, Omdurman, Sudan

${ }^{3}$ Department of Animal Production, Faculty of Natural Resources and Environmental Studies, University of Kordofan, Sudan
Received: 11 October, 2021

Accepted: 29 November, 2021

Published: 30 November, 2021

*Corresponding authors: Mohammed Alhadi Ebrahiem, Department of Animal Production, Faculty of Natural Resources and Environmental Studies, University of Kordofan, Sudan,

E-mail:mahaali5656@gmail.com

ORCID: https://orcid.org/0000-0003-545-1242

Keywords: GMP; SSOP; HACCP; Sugar industry; Sugar factory

Copyright: (C) 2021 Babeker AM, et al. This is an open-access article distributed under the terms of the Creative Commons Attribution License, which permits unrestricted use, distribution, and reproduction in any medium, provided the original author and source are credited.

https://www.peertechzpublications.com

Check for updates

\section{Abstract}

The present study was conducted in Sudan Sugar industry factories (Kenana, White Nile, Assalaya, Sennar, Guneid, and New Halfa) during the production season of 2017. The study aimed to evaluate the existing Assessment of the extent of implementing the Good Manufacturing Practices (GMPs) and Hazard Analysis Critical Control Point System (HACCP) by Sudanese sugar factories with reference to FSMS of the ISO 22000: 2005. The data were collected using ISO 22000 checklist and direct interviews. Likert Five-Point Scale was used in scoring the checklist statement and the arithmetic mean was obtained. The result showed that the Good Manufacturing Practices were varied between major deficiencies in White Nile, Assalaya, Sennar, and New Halfa due to score less than (3.6 points) and non-compliance in Kenana and Guneid due to score less than (2.6 points); the Sanitation Standard Operation Procedures (SSOP) assessed as major deficiencies in (Assalaya and Sennar) and minor deficiencies in (White Nile and New Halfa) due to score less than (5points). Moreover, the Hazard Analysis and Critical Control Points System revealed that it was varied between non-compliance in (Kenana, White Nile, and Guneid) and not applicable in (Assalaya, Sennar and New Halfa) due to score less than (1.8 points). Interestingly, the Sudanese sugar industries take all quality control characteristics from cane production to sugar production carefully, but unfortunately don't care about any food safety systems. Lack of top management commitment and involvement and lack of government support represent the main constraints and Barriers of implementing food safety systems in Sudanese sugar companies. The study recommendations that the Sudanese Sugar Industry needs to establish proper quality assurance laboratories to help in monitoring the quality and safety of raw materials and end productions.

\section{Introduction}

Food manufacturing and producing industries should follow and adopt Good Manufacturing Practices (GMPs) [1] to make sure that all products are manufactured in a safe and healthy environment, which ensures the safety and quality of their products to fulfill the requirement of standards regulations [26]. GMPs are regulations given to ensure effective hazard-free overall practices to ensure product quality, safety, and standards (PQSS) $[1,4,5]$. GMPs must follow various practices of product testing, manufacturing, storage, handling, and distribution. GMPs should fulfill the standards of Safety, Integrity, Purity, Quality, and Composition (SISPQC) $[1,5]$. The practices of Hazard Analysis and Critical Control Points (HACCP) and GMP programs give confidence and faith to consumers that proper testing consistency and safety and quality checks have been maintained throughout manufacturing, packaging, and distribution of products [5]. GMP is a risk assessment trial and it is currently adopted by industries to ensure the PQSS [1,68]. GMP has science and technology-based rules, regulations 
and standards. It also has an integrated systems approach for quality, facilities and equipment, materials, production, packaging, labeling, and laboratory control. It keeps proper records for proposed amendments regarding validation and cross-contamination $[3,4,9]$.

HACCP is well recognized in the food industry as an effective approach to establishing good production, sanitation, and manufacturing practices that produce safe foods $[4,10]$. HACCP is a system of process control used by the industry to prevent hazards to the food supply and as a tool in the control, reduction, and prevention of pathogens in food. HACCP make GMP complete. It is very important and need to be strictly observed by any food industry. First of all HACCP program was developed in the 1960s for NASA to ensure the safety of food products that were to be used by the astronauts in the space program $[1,4,5,8]$

\section{Why GMP / HACCP is required?}

GMP or HACCP establishes minimum GMP for methods to be used and the facilities or controls to be used for, the manufacture, processing, packing, or holding of a food or drug to assure that the food or drug is: safe, has the appropriate identity, purity, and strength, meets quality and purity characteristics $[4,8]$. Food safety and quality control are essential in ensuring that food aid supplies are safe, of good quality, and available in adequate amounts, in time, at affordable prices to ensure an acceptable nutritional and health status for all population groups [5]. HACCP, GMP, ISO, WHO [2], and Codex Alimentarius are major food safety and quality systems [5,11]. GMP is a system to ensure that products meet food PQSS and legal requirements. HACCP can be part of GMP and is a systematic program to assure food safety $[4,7,12]$. GMP provides a high-level assurance that food items, drugs, or medicines are manufactured in a way that ensures their safety, efficacy, and quality and also gives marketing authority with stability $[1,5,6,8,13]$. So this trial was aimed to evaluate the existing Assessment of the extent of implementing the Good Manufacturing Practices (GMPs) and Hazard Analysis Critical Control Point System (HACCP) by Sudanese sugar factories with reference to FSMS of the ISO 22000: 2005.

\section{Materials and methods}

\section{The study area}

Sudan (longitudes $22^{\circ}-38^{\circ}$ East and latitudes $4^{\circ}-22^{\circ}$ North) has numerous natural resources and potentials that can provide abundant inputs for industrial production. Most important of these are the agricultural elements and products that can ensure raw materials for many foodstuff industries, including sugar refining. Moreover, there are vast arable lands (about two hundred million feddans) and many assisting factors, such as the appropriate climate, fertile soil, labor, and reasonable infrastructures that provide greater potential for growing sugar cane, which is the mainstay of the sugar industry in Sudan. The sugar industry of Sudan started with the establishment of the Guneid Sugar Factory in the Gazira province in 1962. There are now five sugar factories in the country, four of these factories are state-owned: The Guneid Factory, the New Halfa Factory, the Sennar Factory, and the Assalaya Factory. The fifth one, The Kenana Factory, is a joint venture with Sudanese, Arab, and other capital, formed in 1975. Kenana Sugar Factory is one of the biggest integrated sugar refineries placed under one administrative body in the world. Its total annual production has reached 300,000 tons of white sugar. This factory is a perfect example of successful joint venture projects in Sudan. It produces a variety of products: white sugar, sugar cubes, sugar syrup, and molasses. The Factory produces briquettes and animal fodder from the remnants of sugar cane [14-23].

This study was conducted in sugar industry factories in Sudan (New Halfa, Guneid, Assalaya, Sennar, Kenana, and White Nile). Numerical scores were given to sanitary observation on 5 classes of complementary conditions: 5- full compliance, 4- minor deficiency, 3- major deficiency, 2- noncompliance, and 1- not applicable. These classifications were developed accordingly to the issued standards criteria.

\section{Data collection}

The data collection was done through an observation checklist and direct interviews with top management and senior managers in the production line. Six visits were carried out to sugar factories to evaluate the existing situation of food safety management system (ISO 22000) and their prerequisites programmers in the Sudanese Sugar industries based on the standard issued by the International Standardization Organization (ISO 22000:2005) and evaluation of each factory performance was documented.

Assessment of good manufacturing practices and hazard analysis and critical control points system

Audit checklist: This assessment was carried out by using the Audit Checklist as prepared by Total Quality Certification Services International TOCSI, 2012). The scoring system was used to evaluate the implementation of the Food Safety Management System as follows in Tables 1-3 according to Likert Five-Point Scales.

Section (1) Assessment of Good Manufacturing Practices (GMP) in Sudanese sugar industries

Section (2) Assessment of Standard Sanitation Operations Procedure (SSOP) in Sudanese sugar industries

Section (3) Assessment of Hazard Analysis and Critical Control Points System in Sudanese sugar industries

Table 1: Scoring system for questions of Food Safety Management System.

\begin{tabular}{|c|c|c|c|c|}
\hline \multicolumn{5}{|c|}{ Possible answer } \\
\hline Strongly Agree & Agree & Neither agree or disagree & Disagree & $\begin{array}{l}\text { Strongly } \\
\text { Disagree }\end{array}$ \\
\hline \multicolumn{4}{|c|}{ Possible Points for the question } \\
\hline Score $=5$ & Score $=4$ & Score $=3$ & Score $=2$ & Score $=1$ \\
\hline Sorrel Brown, 2010 & &
\end{tabular}

Citation: Babeker AM, Ahmed Al, Ahmed AR, Ebrahiem MA (2021) Assessment of the extent implementing the Good Manufacturing Practices (GMPs) and Hazard Analysis Critical Control Point System (HACCP) in Sudan sugar industry factories. J Agric Sc Food Technol 7(3): 368-373.

DOI: https://dx.doi.org/10.17352/2455-815X.000134 
Table 2: Compliance for questions in Food Safety Management System.

\begin{tabular}{|c|c|}
\hline Answer & Criteria used \\
\hline $\begin{array}{l}\text { Total Compliance } \\
\text { Or Strongly Agree }\end{array}$ & To meet the question and/or compliance criteria in full. \\
\hline $\begin{array}{c}\text { Minor Deficiency } \\
\text { Or Agree }\end{array}$ & $\begin{array}{l}\text { To have minor deficiencies against the question and/or } \\
\text { compliance criteria. To have single or isolated non-severe } \\
\text { deficiencies (usually up to three) against the question and/ } \\
\text { or compliance criteria. To have covered most of the question } \\
\text { compliance criteria, but not all. }\end{array}$ \\
\hline $\begin{array}{l}\text { Major } \\
\text { Deficiency } \\
\text { or } \\
\text { Neither agree or } \\
\text { disagree }\end{array}$ & $\begin{array}{l}\text { To have major deficiencies against the question and/ } \\
\text { or compliance criteria. To have numerous non-severe } \\
\text { deficiencies (usually more than three) against the question } \\
\text { and/or compliance criteria. To have single or isolated severe } \\
\text { deficiencies against the question and/or compliance criteria. To } \\
\text { have covered some of the question compliance criteria, but not } \\
\text { most of it. }\end{array}$ \\
\hline $\begin{array}{c}\text { Non-compliance } \\
\text { or } \\
\text { Disagree }\end{array}$ & $\begin{array}{l}\text { To have not met the question and/or compliance criteria } \\
\text { requirements at all. Having systematic deficiencies against } \\
\text { the question and/or compliance criteria (severe or Non-severe } \\
\text { issue). }\end{array}$ \\
\hline $\begin{array}{c}\text { Not applicable } \\
\text { Or } \\
\text { Strongly Disagree }\end{array}$ & $\begin{array}{l}\text { The requirement described in the question is not applicable for } \\
\text { the operation being Audited. A justification should be provided } \\
\text { in the auditor's comments. Be aware that there Are some } \\
\text { questions that do not allow answering Non-applicable. }\end{array}$ \\
\hline
\end{tabular}

Table 3: Audit scoring summary criteria in case of mean and percentage.

\begin{tabular}{|c|c|c|c|}
\hline \multicolumn{4}{|c|}{ How to explain meaning of arithmetic mean and percentage } \\
\hline \multicolumn{2}{|c|}{$\begin{array}{l}\text { How to explain meaning of arithmetic } \\
\text { mean }\end{array}$} & \multicolumn{2}{|c|}{ How to explain meaning of percentage $\%$} \\
\hline Numerical & Views & Numerical & Views \\
\hline$M<1.8$ & $\begin{array}{l}\text { Not applicable } \\
\text { Or } \\
\text { Strongly Disagree }\end{array}$ & $P<36 \%$ & $\begin{array}{l}\text { Not applicable } \\
\text { Or } \\
\text { Strongly Disagree }\end{array}$ \\
\hline $1.8 \leq \mathrm{M}<2.6$ & $\begin{array}{l}\text { Non-compliance } \\
\text { Or } \\
\text { Disagree }\end{array}$ & $36 \% \leq M<52 \%$ & $\begin{array}{l}\text { Non-compliance } \\
\text { Or } \\
\text { Disagree }\end{array}$ \\
\hline $2.6 \leq M<3.4$ & $\begin{array}{c}\text { Major } \\
\text { Deficiency } \\
\text { Or Neither agree or disagree }\end{array}$ & $52 \% \leq M<68 \%$ & $\begin{array}{c}\text { Major } \\
\text { Deficiency } \\
\text { Or Neither agree or } \\
\text { disagree }\end{array}$ \\
\hline $3.4 \leq M<42$ & $\begin{array}{l}\text { Minor Deficiency } \\
\text { Or Agree }\end{array}$ & $68 \% \leq M<84 \%$ & $\begin{array}{c}\text { Minor Deficiency } \\
\text { Or Agree }\end{array}$ \\
\hline $4.2 \leq M \leq 5$ & $\begin{array}{l}\text { Total Compliance } \\
\text { Or Strongly Agree }\end{array}$ & $84 \% \leq M \leq 100 \%$ & $\begin{array}{l}\text { Total Compliance } \\
\text { Or Strongly Agree }\end{array}$ \\
\hline
\end{tabular}

Sorrel Brown, 2010.

\section{Statistical analysis}

The quantitative collected data was entered and analyzed by using Statistical Packing for Social Sciences (SPSS) version 16. To obtain descriptive statistics of percentages and arithmetic mean through using Likert Five-Point Scales (2010).

\section{Results and discussions}

Evaluation of Good Manufacturing Practices (GMP) in the Sudanese Sugar industry with reference to FSMS of the ISO 22000: 2005

Table 4 shows that the General Arithmetic means of Good Manufacturing Practices were 2.23 and 2.27 reported in factory Kenana and factory Guneid respectively this mean is corresponding the Non-compliance according to FSMS requirements of the ISO 22000: 2005. While the arithmetic means of the factories White Nile, Assalaya, Sennar, and New Halfa were $3.14,2.77,2.73$, and 2.64 respectively as a result, the corresponding major deficiencies when compared to FSMS requirements of the ISO 22000: 2005. Gaps and weak points in Good Manufacturing Practices system in all investigated Sudanese sugar industries represented in not have designated person responsible for the food safety program, The operation has not pest control program, there is no designated area for employees to leave aprons, sleeves, and gloves when on break and before using toilets and there are no designated areas for smoking, eating, chewing and drinking. All requirements mentioned above obtained scores not applicable in the six factories under study. Some requirements obtained score noncompliance in all sugar industries like Employees observed not remove smocks, aprons, sleeves, and gloves when on break and before using the toilets and when going home at the end of their shift and Wall, floor and ceiling are it were not easy to clean.

The requirement of the Sanitation Standard Operation Procedures (SSOP) in Sudanese sugar industries with reference to FSMS of the ISO 22000: 2005

Table 5 shows that the General Arithmetic means of Sanitation Standard Operation Procedures were 3.75 and 3.50 reported in factory White Nile and factory New Halfa respectively this mean is corresponding the minor deficiencies according to FSMS requirements of the ISO 22000: 2005. While the arithmetic means of the factories Assalaya and Sennar were 2.63 for each as a result of the corresponding major deficiencies when compared to FSMS requirements of the ISO 22000: 2005. The arithmetic means of the factories Kenana and Guneid were 2.25 and 2.38 respectively, as a result of the corresponding Non-compliance according to FSMS requirements of the ISO 22000: 2005.

The requirement the elements of Hazard Analysis and Critical Control Points System (HACCPS) in Sudanese sugar industries with reference to FSMS of the ISO 22000: 2005

Table 6 shows that the General Arithmetic means of Hazard Analysis and Critical Control Points System were 2.00 for factories Kenana, White Nile, and Guneid this mean is corresponding the Non-compliance according to FSMS requirements of the ISO 22000: 2005. While the arithmetic means of the factories Assalaya, Sennar, and New Halfa was 1.00 as a result the corresponding not applicable when compared to FSMS requirements of the ISO 22000: 2005. It was concluded that the non-compliance scored in the three factories (Kenana, White Nile, and Assalaya) resulted from all food safety hazards that are reasonably expected to occur in the sugar process line were not identified and recorded. Through the observation, the biological hazard analysis was conducted in three industries mentioned above (Kenana, White Nile, and Assalaya). The rest of the factories did not carry out any hazard analysis in the sugar process line (physical, chemical, and biological). It resulted in all these factories scoring not applicable concerning to $\left(\mathrm{HACCP}_{\mathrm{S}}\right)$. 
Table 4: The requirement of the Good Manufacturing Practices (GMP) in Sudanese sugar industries with reference to FSMS of the ISO 22000: 2005 :

\begin{tabular}{|l|l|l|l|l|l|l|}
\hline & \multicolumn{2}{c}{ Factories } \\
\hline Operations to prevent contamination & Kenana & White Nile & Assalaya & Sennar & Guneid & New Halfa
\end{tabular}

designated person responsible for the food safety program

Al so all chemicals (pesticides, sanitizers, detergent, lubricants, etc.) were not stored securely, safely, and were not labeled correctly

the signs supporting GMP posts were not existed in all expellers

The operation have a pest control program

All storage areas clean, especially the racking structures, ceilings, floor areas by the wall and other hard to reach areas

Materials (commodities, packaging, ingredients, work in progress etc.) properly

marked with rotation codes (receipt dates, manufacture dates, etc.)

Rejected or on hold materials clearly identified and separated from other materials?

Materials (commodities, packaging, ingredients, processing aids, work in progress rotated using FIFO policy

The process flow, facility layout, employee control, utensil, internal vehicle use etc., ensure that finished (processed) products are not contaminated by raw products

All employees wearing outer garments suitable for the operation ( smocks, aprons, sleeves and gloves)

there a designated area for employees to leave aprons, sleeves and gloves when on break and before using toilets

smoking, eating, chewing and drinking confined to designated areas

Employees remove smocks, aprons, sleeves and gloves when on break and before using the toilets and when going home at the end of their shift

$$
\begin{gathered}
\text { External \& internal of the } \\
\text { premises are clean }
\end{gathered}
$$

Wall, floor and ceiling are

$$
\text { easy to clean }
$$

Restroom facilities have adequate Ventilation

Draining system is well designed around and within the plant

Sewage and waste water in the premises are clean

Ground does not allow contamination

Building allows enough lighting, ventilation and movement

The maintenance shop organized -i.e. equipment and spares stored in a neat and tidy fashion?

Toilet facilities and hand-washing station clean

\begin{tabular}{|c|c|c|c|c|c|}
\hline 1 & 1 & 1 & 1 & 1 & 1 \\
\hline 3 & 4 & 4 & 4 & 2 & 3 \\
\hline 2 & 3 & 4 & 2 & 2 & 2 \\
\hline 1 & 1 & 1 & 1 & 1 & 1 \\
\hline 2 & 4 & 4 & 3 & 2 & 4 \\
\hline 3 & 4 & 4 & 4 & 3 & 4 \\
\hline 2 & 3 & 3 & 3 & 3 & 3 \\
\hline 2 & 3 & 3 & 3 & 3 & 3 \\
\hline 3 & 4 & 3 & 3 & 3 & 3 \\
\hline 2 & 4 & 3 & 3 & 3 & 3 \\
\hline 1 & 1 & 1 & 1 & 1 & 1 \\
\hline 1 & 1 & 1 & 1 & 1 & 1 \\
\hline 2 & 2 & 2 & 2 & 2 & 2 \\
\hline 2 & 4 & 3 & 3 & 3 & 3 \\
\hline 2 & 2 & 2 & 2 & 2 & 2 \\
\hline 2 & 3 & 3 & 3 & 3 & 3 \\
\hline 3 & 4 & 3 & 3 & 3 & 3 \\
\hline 2 & 4 & 3 & 3 & 2 & 4 \\
\hline 3 & 4 & 3 & 4 & 3 & 4 \\
\hline 2 & 4 & 3 & 4 & 2 & 3 \\
\hline 3 & 4 & 4 & 4 & 3 & 3 \\
\hline 3 & 4 & 3 & 3 & 2 & 2 \\
\hline 2.23 & 3.14 & 2.77 & 2.73 & 2.27 & 2.64 \\
\hline $\begin{array}{l}\text { Non- } \\
\text { npliance }\end{array}$ & $\begin{array}{c}\text { Major } \\
\text { deficiencies }\end{array}$ & $\begin{array}{c}\text { Major } \\
\text { deficiencies }\end{array}$ & $\begin{array}{c}\text { Major } \\
\text { deficiencies }\end{array}$ & $\begin{array}{c}\text { Non- } \\
\text { compliance }\end{array}$ & $\begin{array}{c}\text { Major } \\
\text { deficiencies }\end{array}$ \\
\hline
\end{tabular}

General Arithmetic means

Verbal

\begin{tabular}{|c|c|c|c|c|c|c|}
\hline \multirow[b]{2}{*}{ Sanitation Practices } & \multicolumn{6}{|c|}{ Factories } \\
\hline & Kenana & White Nile & Assalaya & Sennar & Guneid & New Halfa \\
\hline $\begin{array}{l}\text { Written sanitation standard operating procedures for cleaning and } \\
\text { disinfectants }\end{array}$ & 4 & 4 & 4 & 4 & 4 & 4 \\
\hline There is a check sheet for workers to verify all that have been processed & 2 & 3 & 2 & 2 & 2 & 2 \\
\hline Cleaning and sanitation programs are done every day with records & 2 & 4 & 3 & 3 & 2 & 3 \\
\hline $\begin{array}{l}\text { Are there logs showing that equipment is cleaned and sanitized after } \\
\text { maintenance work has been completed? }\end{array}$ & 2 & 4 & 2 & 2 & 2 & 4 \\
\hline $\begin{array}{l}\text { Are there written cleaning procedures Sanitation Standard Operating } \\
\text { Procedures) for the facility and all equipment? }\end{array}$ & 2 & 4 & 3 & 3 & 3 & 3 \\
\hline $\begin{array}{l}\text { Are sanitation logs on file that show what cleaning was done, when and } \\
\qquad \text { who carried out the cleaning? }\end{array}$ & 2 & 4 & 3 & 3 & 2 & 3 \\
\hline $\begin{array}{l}\text { Is there a routine program and written procedure to validate sanitation } \\
\qquad \text { effectiveness? }\end{array}$ & 2 & 3 & 2 & 2 & 2 & 3 \\
\hline $\begin{array}{l}\text { Is there a log indicating that floor drains are cleaned on a regular basis } \\
\text { (minimum daily in wet and fresh-cut production areas)? }\end{array}$ & 2 & 4 & 2 & 2 & 2 & 4 \\
\hline General Arithmetic means & 2.25 & 3.75 & 2.63 & 2.63 & 2.38 & 3.50 \\
\hline Verbal & $\begin{array}{l}\text { Non } \\
\text { compliance }\end{array}$ & $\begin{array}{c}\text { Minor } \\
\text { deficiencies }\end{array}$ & $\begin{array}{c}\text { Major } \\
\text { deficiencies }\end{array}$ & $\begin{array}{c}\text { Major } \\
\text { deficiencies }\end{array}$ & $\begin{array}{l}\text { Non } \\
\text { compliance }\end{array}$ & $\begin{array}{c}\text { Minor } \\
\text { deficiencies }\end{array}$ \\
\hline
\end{tabular}

Table 5: The requirement of the Sanitation Standard Operation Procedures (SSOP) in Sudanese sugar industries with reference to FSMS of the ISO $22000: 2005$.

Citation: Babeker AM, Ahmed Al, Ahmed AR, Ebrahiem MA (2021) Assessment of the extent implementing the Good Manufacturing Practices (GMPs) and Hazard Analysis Critical Control Point System (HACCP) in Sudan sugar industry factories. J Agric Sc Food Technol 7(3): 368-373.

DOI: https://dx.doi.org/10.17352/2455-815X.000134 
Table 6: The requirement of the elements of Hazard Analysis and Critical Control Points System $\left(\mathrm{HACCP}_{\mathrm{S}}\right)$ in Sudanese sugar industries with reference to FSMS of the ISO 22000: 2005.

\begin{tabular}{|c|c|c|c|c|c|c|}
\hline \multirow[b]{2}{*}{ Hazard analysis } & \multicolumn{6}{|c|}{ Factories } \\
\hline & Kenana & White Nile & Assalaya & Sennar & Guneid & New Halfa \\
\hline $\begin{array}{l}\text { Food safety team conducted a hazard analysis to determine which hazards need } \\
\text { to be controlled, the degree of control required to ensure food safety, and control } \\
\text { measures is required. }\end{array}$ & 2 & 2 & 1 & 1 & 2 & 1 \\
\hline $\begin{array}{l}\text { All food safety hazards that are reasonably expected to occur in sugar process } \\
\text { line were identified and recorded. }\end{array}$ & 2 & 2 & 1 & 1 & 2 & 1 \\
\hline $\begin{array}{l}\text { For each of the food safety hazards identified, the acceptable levels of the food } \\
\text { safety hazard in the end product were determined. }\end{array}$ & 2 & 2 & 1 & 1 & 2 & 1 \\
\hline $\begin{array}{l}\text { hazard assessment conducted to determine, for each food safety hazard } \\
\text { identified, whether its elimination or reduction to acceptable levels }\end{array}$ & 2 & 2 & 1 & 1 & 2 & 1 \\
\hline $\begin{array}{l}\text { Selection and assessment of control measures is capable to preventing, } \\
\text { eliminating or reducing these food safety hazards to defined acceptable levels. }\end{array}$ & 2 & 2 & 1 & 1 & 2 & 1 \\
\hline $\begin{array}{l}\text { Monitoring systems were established for each CCP to demonstrate that the CCP } \\
\text { is in control. }\end{array}$ & 2 & 2 & 1 & 1 & 2 & 1 \\
\hline $\begin{array}{l}\text { Corrective actions were taken when critical limits are exceeded shall be } \\
\text { specified in the HACCP plan. }\end{array}$ & 2 & 2 & 1 & 1 & 2 & 1 \\
\hline $\begin{array}{l}\text { Verification process is essential for the successful implementation of the } \\
\qquad \text { HACCP plan. }\end{array}$ & 2 & 2 & 1 & 1 & 2 & 1 \\
\hline General Arithmetic means & 2.00 & 2.00 & 1.00 & 1.00 & 2.00 & 1.00 \\
\hline Verbal & $\begin{array}{c}\text { Non- } \\
\text { compliance }\end{array}$ & $\begin{array}{c}\text { Non- } \\
\text { compliance }\end{array}$ & $\begin{array}{c}\text { Not } \\
\text { applicable }\end{array}$ & $\begin{array}{c}\text { Not } \\
\text { applicable }\end{array}$ & $\begin{array}{l}\text { Non- } \\
\text { compliance }\end{array}$ & Not applicable \\
\hline
\end{tabular}

\section{Conclusion}

The elements of Good Manufacturing Practices were varied between major deficiencies and non-compliance. The recorded gaps and weak points, in the Good Manufacturing Practices system in sugar industries, were because there is no designated person responsible for the food safety program; the operation has not pest control program; there is no designated area for employees to leave aprons, sleeves, and gloves when on break and before using toilets; there are no designated areas for smoking, eating, chewing and drinking. Concerning the elements of Sanitation Standard Operation Procedures (SSOP) assessed as minor deficiencies and major deficiencies according to FSMS requirements of the ISO 22000: 2005. Assessment of the elements of Hazard Analysis and Critical Control Points System revealed that it was varied between non-compliance and not applicable when compared to FSMS requirements of the ISO 22000: 2005. The non-compliance scored in three factories because all food safety hazards that are reasonably expected to occur in the sugar process line were not identified and recorded. Sudanese sugar industries were adopted a quality management system at all levels of the production line but have not adopted any food safety systems.

\section{Recommendations}

In order to control the food hazards, food establishments and government should put measures in place that improve the effects. In-job and in-class training should be conducted to the improve knowledge of employees and managers. Education and training are required for the effective management of HACCP practices. Resources such as human resources, money, equipment monitoring, and training aids should be obtainable for the successful management of food safety practices. Provision of laws and regulations is necessary to guide food safety products in the Sudanese Sugar Industries. Sudanese
Sugar Industry needs to establish some Food Safety systems like Good Agricultural Practices, Good Storage Practices, prerequisite programmers (GMP and SSOP) that represent minimum requirements to implement FSMS.

\section{References}

1. Health Canada (2009) Good Manufacturing Practices (GMP): Guidelines. Version GUI-0001, 21 CFR part 210 and 211.

2. FAO (2014) The joint FAO/WHO expert meeting on microbiological hazards in spices and dried aromatic herbs FAO.

3. Digambar C (2014) Nutraceutical and functional food regulations in the United States and around the World. In: A volume in Food Science and Technology. Canada. Second edition 55-61.

4. FDA (1997) Good Manufacturing Practice (GMP): Guidelines/Inspection Checklist. Link: https://bit.ly/3rmE1Yr

5. Hoffmann S (2011) US food safety policy enters a new era. Amber Waves 9. Link: https://bit.ly/3xCfaki

6. NHPD (2006) Good manufacturing practices: Guidance document. Natural Health Products Directorate (NHPD), Health Canada. Link: https://bit.ly/3ro8KEu

7. Pierson MD, Corlett DA (1992) Principles and guidelines for HACCP. Van Nostrand Reinhold, New York.

8. FDA (2011) Proposed Rule Current Good Manufacturing Practice and Hazard Analysis and Risk-Based Preventive Controls for Human Food. Link: https://bit.ly/3I93qus

9. CAC (2003) Recommended international code of practice - general principles of food hygiene. CAC/RCP1-1969,

10. Sikora T (2015) Good manufacturing practice (GMP) in the production of dietary supplements, Dietary Supplements, Safety, Efficacy and Quality. In: A volume in Woodhead Publishing Series in Food Science, Technology and Nutrition 25-36.

11. Food Chemicals Codex. Link: https://bit.ly/3I5WQVK 
12. FDA (2011) FDA Foods Program, The Reportable Food Registry: A New Approach to Targeting Inspection Resources and Identifying Patterns of Adulteration. Second Annual Report. Link: https://bit.ly/3o8pJc1

13. Murugan V, Mukherjee PK, Venkatesh M (2007) Overview on the development in regulation and control of medicinal and aromatic plants in the Indian system of medicine. Bol. Latinoam Caribe Plant Med. Aromat 6: 129-136. Link: https://bit.ly/31dPLSq

14. Sudan Ministry of Industry and Trade (2021) Sugar Industry. Sudan Trade Point. Copyrights Reserved to Sudan Trade Point. Link: https://bit.ly/3p9DZR3

15. Debasis B (2008) Nutraceutical and functional food regulations in the United States and around the world. Second edition, Department of Pharmacological and Pharmaceutical Sciences, College of Pharmacy, University of Houston, Houston - USA. Link: https://bit.ly/3D7QmSk

16. CAC (1995) Code of hygienic practice for spices and dried aromatic plants CAC/RCP42. Link: https://bit.ly/3I36Te9

17. FDA (2010) Guidance for Industry: Current Good Manufacturing Practice in Manufacturing, Packaging, Labeling, or Holding Operations for Dietary Supplements; Small Entity Compliance Guide.
18. FDA (2010) New Dietary Ingredients in Dietary Supplements - Background for Industry, What Information Must the Notification Contain? Link: https://bit.ly/3d0EsPV

19. International Standard Organization ISO (2005) Food safety management systems: Requirements for any organization in the food chain. International Standard ISO, Switzerland. Link: https://bit.ly/2ZAZfWX

20. ISO (2005) Food safety management systems: Requirements for any organization in the food chain. International Standard ISO, Switzerland. Link: https://bit.ly/3o5BdN8

21. Soares NF, Vicente AA, Martins CMA (2016) Food safety in the seafood industry: A practical guide for ISO 22000 and FSSC 22000 implementation. Link: https://bit.ly/3GfWb2r

22. Soman R, Raman M (2016) HACCP system - hazard analysis and assessment based on ISO 22000:2005 methodologies. Food Control 69: 191-195. Link: https://bit.ly/3xzOC3n

23. Brown S (2010) Likert Scale Examples for Surveys ANR Program Evaluation lowa State University Extensionn. Link: https://bit.ly/3EcpYbt

\section{Discover a bigger Impact and Visibility of your article publication with} Peertechz Publications

\section{Highlights}

* Signatory publisher of ORCID

* Signatory Publisher of DORA (San Francisco Declaration on Research Assessment)

* Articles archived in worlds' renowned service providers such as Portico, CNKI, AGRIS, TDNet, Base (Bielefeld University Library), CrossRef, Scilit, J-Gate etc.

* Journals indexed in ICMJE, SHERPA/ROMEO, Google Scholar etc.

* OAI-PMH (Open Archives Initiative Protocol for Metadata Harvesting)

* Dedicated Editorial Board for every journal

* Accurate and rapid peer-review process

* Increased citations of published articles through promotions

* Reduced timeline for article publication

Submit your articles and experience a new surge in publication services (https://www.peertechz.com/submission).

Peertechz journals wishes everlasting success in your every endeavours.

Citation: Babeker AM, Ahmed Al, Ahmed AR, Ebrahiem MA (2021) Assessment of the extent implementing the Good Manufacturing Practices (GMPs) and Hazard Analysis Critical Control Point System (HACCP) in Sudan sugar industry factories. J Agric Sc Food Technol 7(3): 368-373. 